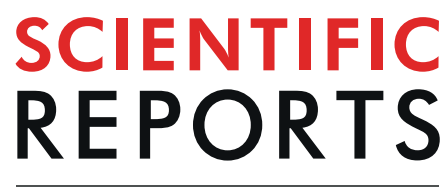

natureresearch

\title{
OPEN Retraction Note: Oncogenic transformation of human lung bronchial epithelial cells induced by arsenic involves ROS-dependent activation of STAT3-miR-21-PDCD4 mechanism
}

\author{
Poyil Pratheeshkumar, Young-Ok Son, Sasidharan Padmaja Divya, Lei Wang, Zhuo Zhang \& \\ Xianglin Shi
}

Retraction of: Scientific Reports https://doi.org/10.1038/srep37227, published online 23 November 2016

The editors are retracting this article.

During an investigation into an allegation of research misconduct at the University of Kentucky, where the research was conducted, it was determined that the article contains fabricated and/or falsified data ${ }^{1}$.

Specifically, in Figure 2D pSTAT3 control image contains no pixel data. The raw data and metadata for this figure are not available. Figure $3 \mathrm{E}$ contains inappropriate scale bars, which use incorrect unit. No scale bars were recorded in the original data; as such the veracity of the scale bars shown cannot be confirmed. pSTAT3 control images in this figure contain no pixel data. Metadata and raw data for figure components in panel $3 \mathrm{E}$ are not available.

Since these data are critical to certain main conclusions of the study, the editors retract this article.

Poyil Pratheeshkumar, Lei Wang, and Xianglin Shi do not agree with the retraction. Young-Ok Son, Sasidharan Padmaja Divya, and Zhuo Zhang could not be reached.

\section{Reference}

1. Results of Official Investigation into Research Misconduct at University of Kentucky. https://www.uky.edu/prmarketing/statementresearch-misconduct (2019).

\begin{abstract}
Open Access This article is licensed under a Creative Commons Attribution 4.0 International License, which permits use, sharing, adaptation, distribution and reproduction in any medium or format, as long as you give appropriate credit to the original author(s) and the source, provide a link to the Creative Commons license, and indicate if changes were made. The images or other third party material in this article are included in the article's Creative Commons license, unless indicated otherwise in a credit line to the material. If material is not included in the article's Creative Commons license and your intended use is not permitted by statutory regulation or exceeds the permitted use, you will need to obtain permission directly from the copyright holder. To view a copy of this license, visit http://creativecommons.org/licenses/by/4.0/.
\end{abstract}

(C) The Publisher 2019 